Please do not remove this page

RMIT

UNIVERSITY

\title{
The politics of biodiversity offsetting across time and institutional scales
}

Damiens, Florence; Porter, Elizabeth; Gordon, Ascelin

https://researchrepository.rmit.edu.au/esploro/outputs/9921970222901341/filesAndLinks?institution=61RMIT_INST\&index=null

Damiens, F., Porter, E., \& Gordon, A. (2021). The politics of biodiversity offsetting across time and institutional scales. Nature Sustainability, 4(2), 170-179. https://doi.org/10.1038/s41893-020-00636-9

Document Version: Accepted Manuscript

Published Version: https://doi.org/10.1038/s41893-020-00636-9

Repository homepage: https://researchrepository.rmit.edu.au

(C) The Author(s), under exclusive licence to Springer Nature Limited 2020

Downloaded On 2023/04/26 20:01:45 +1000 
Title: The politics of biodiversity offsetting across time and institutional scales

Florence L. P. Damiens ${ }^{1 *}$, Libby Porter ${ }^{1}$ and Ascelin Gordon ${ }^{1}$

${ }^{1}$ School of Global, Urban and Social Studies, RMIT University, Melbourne, Victoria, Australia

*Correspondence : Florence L. P. Damiens, RMIT University, email: florence.damiens@ rmit.edu.au. 


\begin{abstract}
Biodiversity offsetting - actions aimed to produce biodiversity gains to compensate for development impacts - has become an important but controversial instrument of sustainability governance. To understand how this occurred, we conducted a discourse analysis, iteratively applying a qualitative coding system to 197 policy documents produced between 1958 and 2019 across four institutional scales. We show that offsetting has historically been promoted by reformist approaches, which encourage economic growth without consideration of biocultural limits. More recently, those promoting more transformative approaches have reinterpreted offsetting as an instrument to transition towards sustainable economies respectful of planetary boundaries. However, we show that enacting this approach requires major structural governance changes that challenge the dominance of reformist coalitions across scales. Such changes would need to include a commitment by institutions to renounce non-essential projects and avoid damage and for offset stakeholders to become aware of how their contributions become enrolled in the service of specific discourses. Without such changes, offsetting risks structurally encouraging conservationists to produce natures compatible with a status quo development, rather than to advance transformative practices for biocultural diversity.
\end{abstract}




\section{Introduction}

Biodiversity offsetting, the last step of the mitigation hierarchy ('avoid, minimize, remediate and offset'), is applied when development activities are authorized despite major impacts on biodiversity ${ }^{1}$. It aims to compensate for residual biodiversity losses by generating equivalent gains elsewhere. Often combined with a 'no net loss' (NNL) objective, offsetting has become an important policy instrument across sectors ${ }^{2,3}$, promoted as able to neutralize development impacts on biodiversity ${ }^{4}$. Despite bestpractice guidelines ${ }^{5}$, offsetting and the NNL concept remain controversial. The conservation literature has highlighted the ecological challenges and ethical implications of offsetting ${ }^{6,7}$. Critical research has analysed offsetting as a symptom of neoliberalization in Anglo-American contexts ${ }^{8,9}$ and transnationally ${ }^{10}$. Case-based studies have challenged this narrative, showing hybrid mechanisms ${ }^{11}$ and the involvement of the state and civil society in some offset programmes ${ }^{12}$. While international and transnational debates continue, there is now a proposition to introduce a NNL objective for the post2020 global biodiversity framework of the Convention on Biological Diversity (CBD) ${ }^{13}$. Here, we explore contesting interpretations of offsetting by harnessing critical social sciences to answer the question of which political projects have sat behind different interpretations of biodiversity offsetting. Using a Foucauldian discursive perspective ${ }^{14}$, we apply a qualitative coding system to 197 policy texts from the United States, Australia and Europe, at both international and transnational levels, dating from 1958 to 2019. Our dataset of texts is snowball sampled and includes reports, peer-reviewed articles, acts, presentations, commentaries and websites. We qualitatively code the texts iteratively and construct a schematic representation of the dissemination of environmental discourses and their influence on offsetting terminology. This analysis enables us to develop an interpretive understanding of the politics at play in the evolution of offsetting. It reveals the shifting configurations of competing discourses about offsetting across time and institutional scales. It unravels the dynamic configurations of power to explain how some interpretations of offsetting are rationalized while others fade away. This helps explain apparently mundane policy changes by rendering visible the political projects, discourse coalitions and actors they either benefit or marginalize. We discuss the implications of these findings for the future of offsetting and the NNL concept as policy mechanisms. Hereafter, we use the term 'offsetting' to encompass both 'compensation' and 'offsetting', except in the Results, where the terms are differentiated to highlight change over time. 


\section{Conceptual framework}

Our analysis, grounded in critical qualitative social sciences, relies on a Foucauldian understanding of power and the concepts of genealogy, discourse and discourse coalitions ${ }^{15}$. Following the argumentative discourse analysis literature, we define a discourse as "an ensemble of ideas, concepts and categories through which meaning is given to social and physical phenomena, and which is produced and reproduced through an identifiable set of practices"16.

Each discourse carries a specific set of rationales that define problems and solutions in human-nature relationships ${ }^{17,18}$. Studying discourses matters because a discourse is where knowledge and power meet $^{14,19}$. Actors sharing the same general understanding of a problem can form a discourse coalition, seeking to secure support for their view of reality, to institutionalize their discourse through policy instruments and practices and, in doing so, to reach hegemony ${ }^{20,21}$ (Methods).

Dryzek identified nine environmental discourses that have competed in environmental governance since the 1960s and classified them into Promethean, reformist and radical discourses ${ }^{18}$. Conflicting rationales between Prometheans and radicals have structured environmental debates since the 1960s. Prometheans deny the existence of environmental problems and defend an unconstrained exploitation of natural resources to sustain economic growth. Radical discourses argue that limits to development and a departure from our current politico-economic systems are required to reach sustainability, yet disagree on how to bring about change. In between, reformist discourses argue that environmental problems can be solved and sustainability achieved without renouncing growth but diverge on proposed reforms. These discourses and the categories they belong to thus carry different understandings of what sustainability might entail, ranging from 'status quo' to 'transformative change, ${ }^{, 22}$.

We assume that competing environmental discourses and their coalitions have either mobilized or rejected offsetting as a policy instrument to be institutionalized and that they may have reinterpreted offsetting while doing so. Six of the discourses identified by Dryzek have competed over the meanings of biodiversity offsetting: Prometheans, administrative rationalists, green neoliberals, ecological modernists, survivalists and green radicals (defined in detail in Table 1). 
Table 1. A summary of the literature on competing environmental discourses.

The rows labelled using bracketed numbers are referred to in the text. When two similar discourses are combined in the same column, their differences are highlighted using square brackets.

\begin{tabular}{|c|c|c|c|c|c|}
\hline \multirow[t]{2}{*}{ Discourse name } & \multicolumn{5}{|c|}{ Elements of the discourse } \\
\hline & $\begin{array}{l}\text { 'Sustainability' } \\
\text { approach }\end{array}$ & $\begin{array}{l}\text { Rationales - } \\
\text { causes of } \\
\text { environmental } \\
\text { problems }\end{array}$ & $\begin{array}{l}\text { Rationales - } \\
\text { economic } \\
\text { development }\end{array}$ & $\begin{array}{l}\text { Rationales - } \\
\text { environmental } \\
\text { solutions }\end{array}$ & $\begin{array}{l}\text { Conceptualization of } \\
\text { biodiversity }\end{array}$ \\
\hline \multicolumn{6}{|c|}{ Promethean discourse } \\
\hline Prometheans (1) & $\begin{array}{l}\text { Resistance to } \\
\text { sustainability or } \\
\text { status quo }\end{array}$ & $\begin{array}{l}\text { No recognition } \\
\text { of } \\
\text { environmental } \\
\text { issues } \\
\text { and limits }\end{array}$ & $\begin{array}{l}\text { Laissez-faire, free } \\
\text { enterprise }\end{array}$ & $\begin{array}{l}\text { Streamlining of 'green } \\
\text { tape', freed market, } \\
\text { technology investment }\end{array}$ & Natural resources \\
\hline \multicolumn{6}{|c|}{ Reformist discourses } \\
\hline $\begin{array}{l}\text { Administrative } \\
\text { rationalism (2) }\end{array}$ & Status quo & $\begin{array}{l}\text { Uncontrolled } \\
\text { economic } \\
\text { development }\end{array}$ & $\begin{array}{l}\text { Channelled and } \\
\text { controlled } \\
\text { economic growth }\end{array}$ & $\begin{array}{l}\text { State-based regulation, } \\
\text { state administration, } \\
\text { international } \\
\text { cooperation }\end{array}$ & $\begin{array}{l}\text { Natural resources and } \\
\text { threatened species }\end{array}$ \\
\hline $\begin{array}{l}\text { Green } \\
\text { neoliberalism (3) }\end{array}$ & Status quo & $\begin{array}{l}\text { Poverty, } \\
\text { market failures } \\
\text { and lack of } \\
\text { economic } \\
\text { growth }\end{array}$ & $\begin{array}{l}\text { Fostered, sustained } \\
\text { green growth. }\end{array}$ & $\begin{array}{l}\text { Internalization of } \\
\text { externalities via } \\
\text { market-based } \\
\text { instruments replacing } \\
\text { 'command-and-control' } \\
\text { approaches }\end{array}$ & $\begin{array}{l}\text { Stocks of substitutable } \\
\text { natural capital, } \\
\text { ecosystem services }\end{array}$ \\
\hline $\begin{array}{l}\text { Ecological } \\
\text { modernisation } \\
\text { [Weak ecological } \\
\text { modernisation] } \\
\text { (4) }\end{array}$ & $\begin{array}{l}\text { Major reforms } \\
\text { [status quo or } \\
\text { light reforms] }\end{array}$ & $\begin{array}{l}\text { Inefficiency, } \\
\text { market failures } \\
\text { and poor } \\
\text { integration of } \\
\text { natural capital } \\
\text { in decision } \\
\text { making }\end{array}$ & $\begin{array}{l}\text { Transition towards } \\
\text { a green economy, } \\
\text { decoupling growth } \\
\text { from its } \\
\text { environmental } \\
\text { impacts }\end{array}$ & $\begin{array}{l}\text { State-based [voluntary- } \\
\text { based] regulations, } \\
\text { economic instruments, } \\
\text { polluter-pays principle, } \\
\text { new partnerships } \\
\text { among states, experts, } \\
\text { businesses and civil } \\
\text { societies }\end{array}$ & $\begin{array}{l}\text { Critical natural capital } \\
\text { [downsized critical } \\
\text { natural capital], } \\
\text { substitutable natural } \\
\text { capital and ecosystem } \\
\text { services }\end{array}$ \\
\hline \multicolumn{6}{|l|}{ Radical discourses } \\
\hline Survivalism (5) & $\begin{array}{l}\text { Reforms or major } \\
\text { reforms }\end{array}$ & $\begin{array}{l}\text { Population } \\
\text { growth and } \\
\text { consumption } \\
\text { patterns } \\
\text { exceeding } \\
\text { planetary } \\
\text { boundaries }\end{array}$ & $\begin{array}{l}\text { Transition towards } \\
\text { a post-industrial } \\
\text { system }\end{array}$ & $\begin{array}{l}\text { International } \\
\text { cooperation, science- } \\
\text { based regulation, and } \\
\text { administration }\end{array}$ & $\begin{array}{l}\text { Biodiverse planet with } \\
\text { global boundaries, } \\
\text { unique ecosystems with } \\
\text { limited carrying } \\
\text { capacity and finite } \\
\text { stocks of natural } \\
\text { resources }\end{array}$ \\
\hline $\begin{array}{l}\text { Green radicalism } \\
\text { (6) }\end{array}$ & Transformation & $\begin{array}{l}\text { The dominant } \\
\text { politico- } \\
\text { economic } \\
\text { system itself }\end{array}$ & $\begin{array}{l}\text { Transition towards } \\
\text { a post-industrial } \\
\text { system }\end{array}$ & $\begin{array}{l}\text { Alternative } \\
\text { transnational } \\
\text { cooperation, other } \\
\text { forms of governance, } \\
\text { regulations to protect } \\
\text { nature, local and } \\
\text { Indigenous } \\
\text { communities, the } \\
\text { Commons and } \\
\text { biocultural traditions }\end{array}$ & $\begin{array}{l}\text { Diverse representations } \\
\text { of human-nature } \\
\text { relationships; } \\
\text { biocultural diversity }\end{array}$ \\
\hline
\end{tabular}




\section{Results}

We find three reformist environmental discourses are primarily responsible for mobilizing compensation or offsetting over time: administrative rationalism, neoliberalism and ecological modernization (Table 1, rows 2-4). Emerging successively, each has worked to support compensation or offsetting as a reformist solution in response to tensions between Prometheans and radicals regarding limits to development (Table 1, rows 1,5 and 6). These discourses rely on different forms of knowledge, empower different actors and problematize the impacts of development on biodiversity differently (Table 2, columns 1-4). Consequently, they interpret offsetting differently

and propose different instruments to either operationalize or resist it (Table 2, columns 5 and 6). Tensions around the notion of limits are central to understand changes in offset-related meanings and mechanisms across time and scales.

Figure 1 and Box 1 present a schematic depiction of these discourses along with important events that have triggered specific discursive dynamics. They represent the visualization of our qualitative interpretation, iteratively constructed as part of the analysis, rather than the output of a quantitative coding system. Figure 1 shows at which institutional scale a discourse starts mobilizing (or resists) Environmental Impact Assessment (EIA), permits, compensation or offsetting, how it moves across scales and interacts with other discourses. In the following we describe in detail the dynamics depicted in this figure.

\section{The origins and international dissemination of compensation}

Compensation, applied to environmental governance, has its roots in administrative rationalism. In the 1960s, radical environmental discourses, epitomized by Silent Spring ${ }^{23}$, questioned the growth paradigm and called for limits on economic development and pollution (Fig. 1, location 1 and Table 1, rows 5 and 6). In reaction, an administrative rationalist discourse expanded, arguing that environmental problems could be solved without renouncing growth (Table 1, row 2). This discourse rationalized legislation, standards, permits and EIA in 1970s US policy to prevent and minimize the adverse effects of development. Mitigation and compensation were introduced in the emerging conservation-related legislations in the United States, within Europe and in the Ramsar Convention to repair damage (Fig. 1, locations 2) and progressively included in EIA guidance texts. Given US influence, EIA rapidly disseminated in Australia, Europe and internationally (Fig. 1, locations 3). The idea of producing nature as a form of compensation was also developed and then mainstreamed to mitigate wetland loss in the United States. In-kind compensation had already been institutionalised in Europe before the 1960s to manage forest clearance (Fig. 1, locations 4).

Compensatory measures were applied to biodiversity and travelled beyond Western countries with the sustainable development agenda. In the 1980s, survivalist rationales spread across the emerging transnational field of conservation biology, articulating the limited carrying capacity of ecosystems facing the impacts of development and population growth (Fig. 1, location 5). In reaction, the sustainable development agenda was articulated, epitomized by the Brundtland report ${ }^{24}$, yet remained ambiguous over ecological limits. Green radical coalitions denounced the World Bank and extractive industries for human rights violations and environmental disasters; they responded to this pressure by developing new international EIA guidelines. With the Rio Summit and the CBD, biodiversity was afforded greater protection with prevention, minimization and compensation measures entering international EIA standards, influencing regulations and guidelines across scales (Fig. 1, locations 6). 
Table 2. Effects of environmental discourses on the empowered knowledges, actors, rationales, definitions and instruments associated with offsetting.

The columns and rows labelled using bracketed numbers are referred to in the text. When two similar discourses are combined in the same column, their differences are highlighted using square brackets.

\begin{tabular}{|c|c|c|c|c|c|c|}
\hline \multirow{2}{*}{$\begin{array}{l}\text { Discourse } \\
\text { name }\end{array}$} & \multicolumn{6}{|c|}{ Effects of the discourse } \\
\hline & $\begin{array}{l}\text { Empowered } \\
\text { knowledges (1) }\end{array}$ & $\begin{array}{l}\text { Empowered } \\
\text { actors (2) }\end{array}$ & $\begin{array}{l}\text { Problematization - } \\
\text { Impacts of } \\
\text { development on } \\
\text { biodiversity (3) }\end{array}$ & $\begin{array}{l}\text { Problematization - } \\
\text { Limits to } \\
\text { development and to } \\
\text { authorised losses (4) }\end{array}$ & $\begin{array}{l}\text { Definition of } \\
\text { offsetting (5) }\end{array}$ & $\begin{array}{l}\text { Instruments mobilized to } \\
\text { institutionalize or resist to } \\
\text { offsetting (6) }\end{array}$ \\
\hline \multicolumn{7}{|c|}{ Promethean discourse } \\
\hline $\begin{array}{l}\text { Prometheans } \\
\text { (1) }\end{array}$ & $\begin{array}{l}\text { Economics, } \\
\text { business }\end{array}$ & $\begin{array}{l}\text { Businesses, the } \\
\text { market }\end{array}$ & Unproblematic & No limits & $\begin{array}{l}\text { A green tape } \\
\text { burden that } \\
\text { hinders } \\
\text { development }\end{array}$ & $\begin{array}{l}\text { Refusal to pay or preference } \\
\text { for monetary fees, } \\
\text { suppression or simplification } \\
\text { of offset standards }\end{array}$ \\
\hline \multicolumn{7}{|c|}{ Reformist discourses } \\
\hline $\begin{array}{l}\text { Administrative } \\
\text { rationalism (2) }\end{array}$ & $\begin{array}{l}\text { Engineering, } \\
\text { natural resource } \\
\text { management, } \\
\text { planning }\end{array}$ & $\begin{array}{l}\text { Strong central } \\
\text { state, engineers, } \\
\text { scientists, } \\
\text { international } \\
\text { agencies }\end{array}$ & $\begin{array}{l}\text { Morally } \\
\text { problematic, if } \\
\text { above acceptable } \\
\text { levels }\end{array}$ & $\begin{array}{l}\text { Ambiguous limits: } \\
\text { no loss above } \\
\text { acceptable levels, } \\
\text { mitigate losses below } \\
\text { acceptable levels }\end{array}$ & $\begin{array}{l}\text { A last resort } \\
\text { measure to } \\
\text { mitigate } \\
\text { unavoidable } \\
\text { damage or } \\
\text { repair harm }\end{array}$ & $\begin{array}{l}\text { Planning, conservation } \\
\text { regulation, permit } \\
\text { conditions, EIA, mitigation } \\
\text { hierarchy, monetary or in- } \\
\text { kind compensation (on-site } \\
\text { measures or new } \\
\text { conservation reserves) }\end{array}$ \\
\hline $\begin{array}{l}\text { Green } \\
\text { neoliberalism } \\
(3)\end{array}$ & $\begin{array}{l}\text { Economics, } \\
\text { environmental } \\
\text { economics, } \\
\text { business }\end{array}$ & $\begin{array}{l}\text { The market, } \\
\text { businesses, } \\
\text { consultants, } \\
\text { financial } \\
\text { institutions, } \\
\text { service providers, } \\
\text { informal } \\
\text { transnational } \\
\text { networks }\end{array}$ & $\begin{array}{l}\text { Market failure if the } \\
\text { total stock of } \\
\text { substitutable natural } \\
\text { capital is not } \\
\text { maintained }\end{array}$ & $\begin{array}{l}\text { No limits: losses in } \\
\text { values are traded } \\
\text { with gains, to reach a } \\
\text { NNL in exchanged } \\
\text { values }\end{array}$ & $\begin{array}{l}\text { A win-win } \\
\text { cost-efficient } \\
\text { opportunity for } \\
\text { businesses } \\
\text { (social licence } \\
\text { to operate), } \\
\text { investors (risk } \\
\text { management) } \\
\text { and } \\
\text { conservation } \\
\text { (funding) }\end{array}$ & $\begin{array}{l}\text { Voluntary offset standards, } \\
\text { minimum regulation to } \\
\text { establish offset banking } \\
\text { mechanisms and offset } \\
\text { service markets, objective of } \\
\text { a NNL in value }\end{array}$ \\
\hline $\begin{array}{l}\text { Ecological } \\
\text { modernisation } \\
\text { [Weak } \\
\text { ecological } \\
\text { modernisation] } \\
(4)\end{array}$ & $\begin{array}{l}\text { Ecological } \\
\text { engineering, } \\
\text { environmental } \\
\text { and ecological } \\
\text { economics, } \\
\text { natural resource } \\
\text { management, } \\
\text { conservation } \\
\text { planning }\end{array}$ & $\begin{array}{l}\text { Strong state [small } \\
\text { state], businesses, } \\
\text { [large] NGOs, } \\
\text { ecological } \\
\text { engineers, experts, } \\
\text { consultants, } \\
\text { researchers, } \\
\text { informal } \\
\text { transnational } \\
\text { networks }\end{array}$ & $\begin{array}{l}\text { Economic } \\
\text { inefficiency if } \\
\text { development is not } \\
\text { decoupled from its } \\
\text { biodiversity impacts } \\
\text { and affects the } \\
\text { critical natural } \\
\text { capital }\end{array}$ & $\begin{array}{l}\text { Ambiguous limits: } \\
\text { loss of critical } \\
\text { natural capital is not } \\
\text { acceptable [unless } \\
\text { technological } \\
\text { innovation expands } \\
\text { ecological limits]; } \\
\text { acceptable losses in } \\
\text { non-critical capital } \\
\text { need to be offset to } \\
\text { reach a NNL in } \\
\text { natural capital. }\end{array}$ & $\begin{array}{l}\text { The last step of } \\
\text { the mitigation } \\
\text { hierarchy to } \\
\text { ensure an } \\
\text { overall NNL or } \\
\text { net gain and } \\
\text { support the } \\
\text { transition } \\
\text { through price } \\
\text { signals }\end{array}$ & $\begin{array}{l}\text { Planning and conservation } \\
\text { regulation, with a net-gain } \\
\text { objective in natural capital at } \\
\text { the landscape level, permit } \\
\text { conditions, EIA, mandatory } \\
\text { [voluntary] offset standards } \\
\text { (mitigation hierarchy, offsets } \\
\text { for residual impacts, } \\
\text { measurable, additional, like- } \\
\text { for-like or better gains, } \\
\text { retainment in perpetuity for } \\
\text { permanent impacts), offset } \\
\text { compliance markets with a } \\
\text { preference for banking } \\
\text { mechanisms }\end{array}$ \\
\hline \multicolumn{7}{|c|}{ Radical discourses } \\
\hline Survivalism (5) & $\begin{array}{l}\text { Ecology, } \\
\text { conservation } \\
\text { biology, natural } \\
\text { resource } \\
\text { management, } \\
\text { conservation } \\
\text { planning }\end{array}$ & $\begin{array}{l}\text { Strong central } \\
\text { state, international } \\
\text { agencies, } \\
\text { conservation and } \\
\text { climate scientists, } \\
\text { some grass-root } \\
\text { movements }\end{array}$ & $\begin{array}{l}\text { Immoral: } \\
\text { biodiversity loss is } \\
\text { irreplaceable }\end{array}$ & $\begin{array}{l}\text { Strong limits: no loss } \\
\text { of biodiversity; } \\
\text { impacts are } \\
\text { acceptable if they } \\
\text { affect highly } \\
\text { modified or highly } \\
\text { degraded ecosystems }\end{array}$ & $\begin{array}{l}\text { At best, a } \\
\text { deterrent to } \\
\text { development; at } \\
\text { worst, a license } \\
\text { to destroy, } \\
\text { undermining } \\
\text { conservation } \\
\text { efforts }\end{array}$ & $\begin{array}{l}\text { Planning and conservation } \\
\text { regulation focused on } \\
\text { protection (no-go zones, } \\
\text { renouncement, alternative } \\
\text { projects, avoidance), } \\
\text { compensation limited to } \\
\text { residual impacts on highly } \\
\text { modified or highly degraded } \\
\text { ecosystems only }\end{array}$ \\
\hline $\begin{array}{l}\text { Green } \\
\text { radicalism (6) }\end{array}$ & $\begin{array}{l}\text { Indigenous and } \\
\text { traditional } \\
\text { knowledges, } \\
\text { ecological } \\
\text { economics, } \\
\text { critical social } \\
\text { sciences, } \\
\text { humanities }\end{array}$ & $\begin{array}{l}\text { Decentralised } \\
\text { state, civil } \\
\text { societies, } \\
\text { Indigenous } \\
\text { peoples, grass-root } \\
\text { movements, social } \\
\text { scientists, Nature }\end{array}$ & $\begin{array}{l}\text { Immoral: biocultural } \\
\text { losses are } \\
\text { irreplaceable; } \\
\text { Ecocide is a crime }\end{array}$ & $\begin{array}{l}\text { Strong limits: no loss } \\
\text { of biocultural } \\
\text { diversity }\end{array}$ & $\begin{array}{l}\text { A license to } \\
\text { destroy, } \\
\text { commodifying } \\
\text { nature, and } \\
\text { undermining } \\
\text { urgent } \\
\text { transformative } \\
\text { changes }\end{array}$ & $\begin{array}{l}\text { Other systems of } \\
\text { governance, conservation } \\
\text { regulation focused on } \\
\text { prevention (no-go zones, } \\
\text { renouncement, avoidance, } \\
\text { limits to what can be } \\
\text { ecologically and socially } \\
\text { offset), fair social and } \\
\text { ecological compensation }\end{array}$ \\
\hline
\end{tabular}


Fig. 1. Schematic representation of the dissemination of environmental discourses and their influence on offsetting through time and across scales.

Each coloured vertical line represents a different environmental discourse. The point at which lines start represents when a discourse mobilizes (or resists) EIA, granting permits, compensation or offsetting in conventions/laws/policies/guidelines. The horizontal lines depict how the discourses disseminate across different institutional scales. The numbers signify important events, which are described in Box 1.

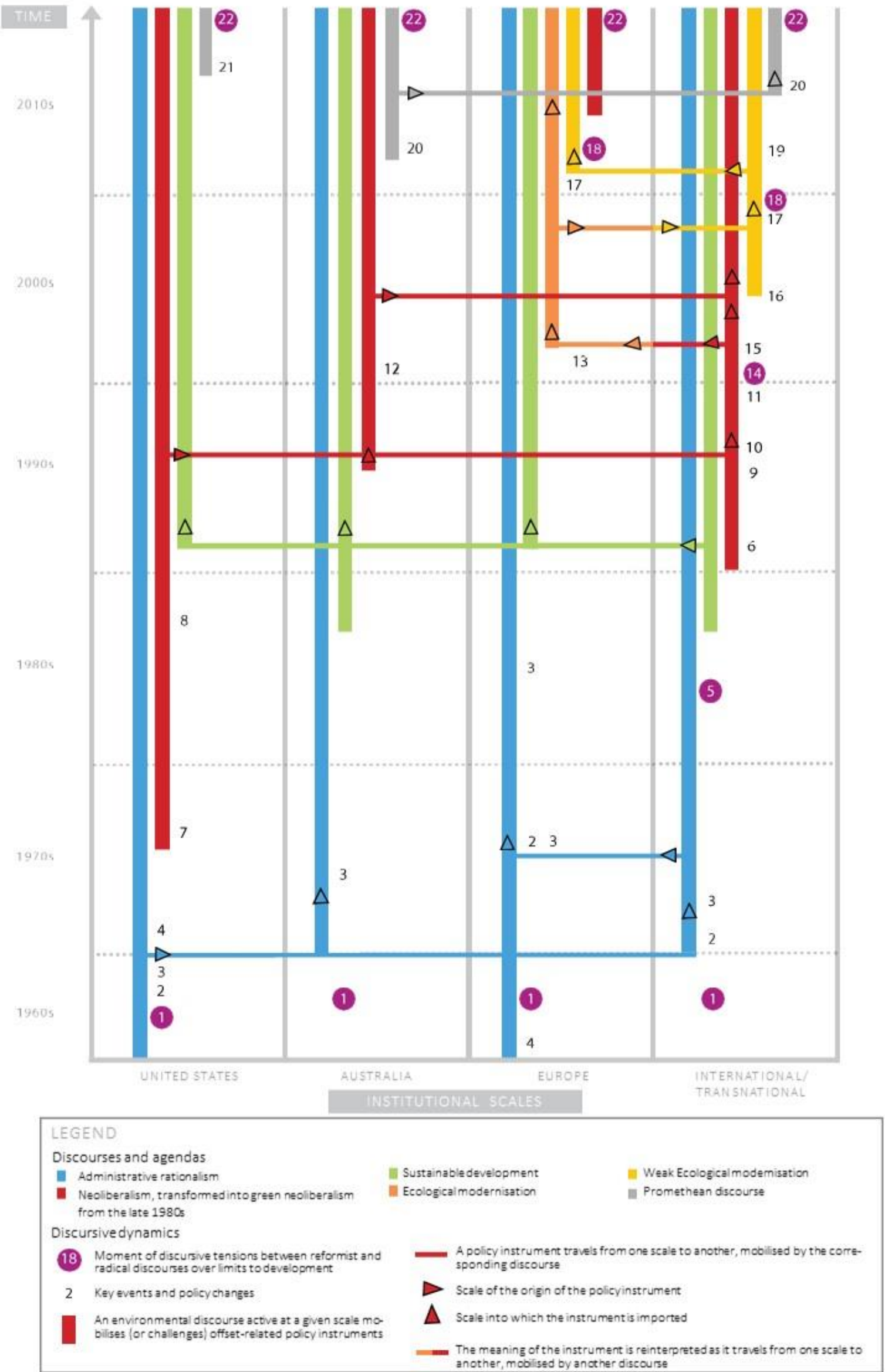




\section{Box 1. Description of the important events triggering major discursive dynamics.}

The following event numbers correspond to those used in Fig. 1and referred to in the text:

(1) Radical environmental discourses arise, questioning the growth paradigm and calling for limits on economic development and pollution.

(2) Mitigation and/or compensation are introduced in conservation-related legislation.

(3) Permits and EIA processes disseminate across scales.

(4) The notion of producing 'nature' as a form of compensation is deployed.

(5) Survivalist discourse emerges, and radical pressures increase on the World Bank and extractive industries.

(6) Biodiversity concerns and compensation for biodiversity are introduced in the CBD, laws and policy texts.

(7) The notions of offsetting and 'no net increase' emerge in the pollution realm following tensions regarding the compliance

of pollution standards.

(8) The NNL concept and banking system are transferred to wetland mitigation following tensions regarding mitigation compliance

and development.

(9) The World Business Council for Sustainable Development promotes a voluntary corporate responsibility and flexible

market-inspired instruments as solutions for sustainable development.

(10) A market-based approach inspired by the US emission trading system is proposed in the Kyoto negotiations on climate change.

(11) The economic conceptualization initially crafted for air and water pollution is transferred to biodiversity with the promotion of market-inspired mechanisms for carbon forestry and forest conservation.

(12) A NNL objective is introduced in native vegetation management within Australia, followed by biodiversity offset obligations and hybrid offset markets.

(13) Carbon offsetting is introduced, alongside new regulations to foster the low-carbon transition in Europe.

(14) The IUCN and transnational NGOs campaign for conservation 'no-go zones' to limit extractive activities in protected areas.

(15) The International Council on Mining and Metals, established with the impulse of Rio Tinto, engaged in informal transnational discussions with the IUCN and major transnational NGOs regarding limits to mining. Voluntary guidelines, offsetting and partnerships between conservation and businesses are proposed as solutions.

(16) BBOP works on offset standards and biodiversity offset mechanisms relying on the terminology and experiences of its US, Australian and other transnational members.

(17) BBOP and its transnational offset standards are legitimated in Europe, internationally and transnationally with the green economy/green growth agenda. The terminology of EIA guidelines shifts from compensation to offsetting. Commitments to net gain and NNL spread beyond Anglo-Saxon countries. Biodiversity offset markets are promoted to meet these new commitments.

(18) Tensions rise within the IUCN, followed by calls for no-go zones, and a radical opposition builds against biodiversity offsetting.

(19) Offset standards are refined, articulating the importance of limits to development and offsetting.

(20) Within Australia, Victoria renounced its net-gain objective and, with New South Wales, weakened its likefor-like offset principle. Rio Tinto renounces its corporate-wide net-positive impact commitment.

(21) Promethean rationales promote the de-institutionalization of wetland protection and permit approval processes in the United States.

(22) International scientific reports and the radicalization of rationales within civil societies, urging transformative change in the face of climate change and biodiversity depletion, bring back strong sustainability on the political agenda. 


\section{The neoliberal origins of offsetting and $N N L$}

The rise of neoliberalism as a new hegemonic discourse plays an important role in explaining the progressive emergence of offsetting, NNL and offset 'markets' in the United States from the mid-1970s. Neoliberalism partially deregulated and re-regulated the state via different instruments, including market-inspired mechanisms. Symptomatic of this hegemonic shift, the idea of offsetting pollution emissions was introduced in the mid-late 1970s to make regulatory compliance more flexible in the face of development pressures (Fig. 1, location 7). Mitigation-related rationales shifted from morality (prevention and penalization in case of damage) towards economic efficiency (internalization of externalities): new emissions could be produced as long as equivalent emissions elsewhere could be mitigated to ensure 'no net increase' in pollution. Emissions therefore became conceptually disconnected from their source in both space and time, and institutional effort shifted from prevention to offsetting. Radicals, calling for limits on emissions, were marginalized.

The NNL concept was then transferred to wetland-related mitigation regulations, which were affecting development without producing satisfactory outcomes ${ }^{25}$ (Fig. 1, location 8). Disconnections from place accelerated with the wetland mitigation banking system in the $1980 \mathrm{~s}^{8}$ and the sulfur dioxide allowance market in the early 1990s. With these changes, green neoliberalism was born (Tables 1 and 2, row 3 ).

\section{Setting the discursive conditions for an offset coalition}

In the late 1980s, green neoliberalist rationales spread beyond the United States via Australia, the World Bank and transnational corporations gathering as the World Business Council for Sustainable Development. These actors promoted voluntary corporate responsibility and flexible market-based instruments for the United Nations Agenda 21 action plan, reframing and eschewing regulations as 'command-and-control' approaches ${ }^{26}$ (Fig. 1, location 9). Flexible mechanisms were first applied to mitigation internationally via the Kyoto negotiations on climate change. The United States, opposed to emission limitations, successfully introduced a market-based approach leading to the Clean Development Mechanism ${ }^{27}$ (Fig. 1, location 10). With this momentum, the World Bank and emerging transnational actors, including the US-based non-governmental organization (NGO) Forest Trends, worked on market-based instruments to foster carbon forestry and forest conservation and transferred to biodiversity an economic conceptualization initially crafted for air and water pollution (Fig. 1, location 11). Australia adapted the biodiversity conservation agenda to its rising neoliberal hegemony in the 1990s and 2000s. Symptomatic of this trend, the states of Victoria and New South Wales progressively introduced a NNL objective, followed by biodiversity offset and hybrid offset markets to manage native vegetation clearing and operationalize EIA-related biodiversity compensation (Fig. 1, location 12).

In parallel, ecological modernization, taking root in Germany and the Nordic countries in the 1980s, spread across Europe with the sustainability agenda, arguing in favour of a transition towards a lowcarbon economy. While sharing some rationales with green neoliberalism, this discourse differs in its regard for the non-substitutability of critical natural capital and a preference for strong state regulation (Table 1, row 4). Following the Clean Development Mechanism and the polluter-pays principle (promoted by the Organisation for Economic Co-operation and Development since the 1970s), carbon offsetting was introduced into the European Union in the early 2000s, alongside new regulations to foster the transition (Fig. 1, location 13). Europe became the new leader in international environmental governance while the United States withdrew, influenced by a rising climatosceptic Promethean coalition (Table 1, row 1).

From the early 2000s, green neoliberalism and ecological modernization were competing across scales. As these discourses merged at the international and transnational levels, a weak form of ecological 
modernization $^{28}$ arose, promoting informal public-private partnerships, voluntary guidelines and technological innovations as solutions. These provided the discursive conditions for the formation of a transnational coalition promoting biodiversity offsetting and its market-inspired approach beyond Anglo-American countries.

\section{Extractive industries, no-go zones and the BBOP}

Radical pressures accelerated in the early 2000s. The objective of halting biodiversity loss was adopted under the CBD, and the extractive sector's social licence to operate was being eroded. The International Union for Conservation of Nature (IUCN) and transnational NGOs campaigned for no-go zones to limit extractive activities in protected areas (Fig. 1, location 14). Transnational mining corporations pushed back against stronger conservation regulations ${ }^{29}$, led by the Anglo-Australian multinational Rio Tinto operating within the World Business Council for Sustainable Development and, later, as the International Council on Mining and Metals (ICMM). This shifting dynamic, combined with the trial of biodiversity-related offsets in the United States and Australia, saw the ICMM engage in informal discussions with the IUCN and major transnational NGOs regarding limits to mining. Instead of no-go zones (reframed as rigid), voluntary guidelines, offsetting, planning and restoration were proposed (Fig. 1, location 15), with the argument that biodiversity could be displaced in a cost-efficient manner. For this to happen, more constructive cooperation was needed between conservation and extractive industries, reframed as 'partners' rather than opponents.

From then, the IUCN and the ICMM encouraged informal networks of stakeholders to develop voluntary offset best-practice guidelines and transform Promethean practices. A heterogeneous transnational coalition, merging green neoliberal and weak ecological modernist rationales, formed and gave birth to the transnational Business and Biodiversity Offset Programme (BBOP) by the mid-2000s. BBOP, as a 'policy entrepreneur' ${ }^{30}$, initially mobilized the terminology and experiences of the United States and Australia and launched industry-led case studies to set its voluntary standards. It framed biodiversity offset mechanisms as 'win-win' service markets, being able to provide developers with a licence to operate and conservation with new sources of funding (Fig. 1, location 16).

\section{Europe and the international legitimization of the $\mathrm{BBOP}$}

Ecological modernist rationales intensified in Europe with the Environment Liability Directive, the Millennium Ecosystem Assessment ${ }^{31}$, The Economics of Ecosystems and Biodiversity reports ${ }^{32}$ and calls for investment in the 'green economy' following the 2008 economic crisis. The polluter-pays principle was transferred to biodiversity, and partnerships between conservation and businesses were promoted. European actors joined BBOP, starting to focus on infrastructure development. With this European momentum, followed soon by the weaker 'green growth' agenda of the Organisation for Economic Co-operation and Development and the World Bank, BBOP and its standards ${ }^{5}$ were legitimated in Europe, which opened the doors of the CBD Conferences of the Parties. With key BBOP promoters intervening across policy texts, the terminology of EIA guidelines shifted from compensation towards offsetting in the 2010s. Commitments to net-gain and NNL objectives spread. Green neoliberals and (weak) ecological modernists promoted offset markets (Fig. 1, location 17), blurring the lines between conservation activities and compensatory obligations under the CBD.

\section{Radical resistances and the renovation of offsetting}

From the late 2000s, internal tensions rose between reformists and radicals within the IUCN. Radicals (Table 2, rows 5 and 6) criticized the partnerships between the IUCN and corporations, such as Shell and Rio Tinto, as 'greenwashing' ${ }^{33}$. Calls for no-go zones returned as the debate about 'planetary boundaries' emerged, biodiversity degradation and Indigenous rights struggles deepened and the climate debate grew ${ }^{34}$. Resistance to biodiversity offsetting strengthened transnationally and within 
Europe in the early 2010s, where questions arose about its ecological validity, practical effectiveness ${ }^{35}$ and risks of marketization (Fig. 1, location 18). These tensions triggered refinement of offset standards, articulating the importance of limits (via no-go zones, limits to what can be offset and the importance of 'additionality', renouncement and the avoidance step of the mitigation hierarchy ${ }^{36}$ ) (Fig. 1, location 19).

Since the mid-2010s, a stronger ecological modernist coalition (mainly active among academic circles and in Europe) has reframed biodiversity offsetting and the net-gain objective as transformative instruments to be mobilized at the landscape scale in addition to stronger conservation regulations. Debates between radicals and reformists continue in Europe regarding offsetting, compliance markets and the risks of lowered protections, notably in Nordic countries, one of the mining frontiers for rareearth metals.

\section{The return of Prometheans and weakened futures}

While reformists faced the resistance of radicals in international, transnational and European circles, they also experienced a backlash from Prometheans and neoliberals in Anglo-American countries from the 2010s (Table 2, rows 1 and 3). In Australia, some states renounced net-gain objectives in 2013 and weakened the like-for-like offset principle ${ }^{37,38}$.

Rio Tinto, despite its transnational leadership role in the BBOP, renounced its corporate-wide netpositive-impact commitment in $2017^{39}$ (Fig. 1, location 20). With the Trump Presidency, Promethean rationales have promoted the de-institutionalization of wetland protection and permit approval processes $^{40}$ (Fig. 1, location 21).

In Europe, the ecological modernist transition weakened, and investments in offset compliance markets remained relatively slow. BBOP was closed in December 2018, with a call for action, highlighting the gap between declarations and enactments ${ }^{41}$. Some former BBOP members continue supporting businesses to deliver net-positive outcomes via new transnational and European networks, such as the Natural Capital Coalition initiative. With the return of Prometheans and international scientific reports urging transformative change in the face of climate change and biodiversity depletion ${ }^{42}$, radical coalitions have brought strong sustainability back to the political agenda (Fig. 1, location 22). 


\section{Discussion}

Our analysis reveals that current offset and mitigation policies organize attention and institutional efforts to reformist understandings of problems and solutions. They are the result of networks of power ${ }^{14,43}$ that structurally encourage the emergence of policies devoted to the re-organization of nature in space (rather than the re-organization of development). They are also a mechanism of power itself ${ }^{14,43}$, as the operationalization of these policies supports the realization of specific political projects.

We challenge previous findings in the critical literature that have analysed offsetting as solely explained by neoliberalism ${ }^{8-10}$. Instead, we show the administrative rationalist origins of offsetting and the competition between different discourse coalitions across time and scales over its meanings. This reveals a deep discursive pattern at play since the 1960s, with reformist rationales and instruments, originally constructed for air and water pollution, being continuously replicated across environmental concerns to appease conflicts between coalitions regarding limits to development. The rise of neoliberalism reframed nature as displaceable objects amenable to re-organization through markets, and the discursive focus progressively shifted from prevention in the 1970s towards mitigation and offsetting. The tensions among radicals, reformists and extractive activities has triggered the mobilization of these rationales and instruments into the field of biodiversity conservation from the late 1980s. This field had previously emerged from heterogeneous radical coalitions based on ecological science and/or Indigenous and traditional knowledge (Tables 1 and 2, rows 5 and 6). Offsetting has remained controversial there precisely because it is the outcome of reformist political projects that have discursively challenged, and sometimes marginalized, more radical commitments to transformative change.

The competition among these coalitions clarifies why the biodiversity-related offset markets widely studied in the literature are better explained as 'hybrids' ${ }^{11,12}$. While green neoliberalism aimed to render biodiversity fungible and operationalize markets to replace state-based regulation, the administrative rationalist legacy and the relative influence of other coalitions at different scales have limited the full materialization of this political project. In practice, neoliberals both resisted and built on the legacy of conservation regulation and the everyday resistance of other coalitions.

Discourses can act both as points of resistance and as openings for new oppositional strategies ${ }^{44}$. For example, the case of ecological modernization shows how NNL and offset markets, despite their neoliberal origin, were reinterpreted to serve other reformist projects (Table 2, row 4). Radical resistance enabled stronger ecological modernists to attempt a reconfiguration of power relations by mobilizing offsetting as a potentially transformative tool if used only for residual impacts and alongside strengthened conservation regulations. Such an attempt offers insights into both the discursive strategies that might be necessary to negotiate radical and reformist agendas and the reconfigurations of power that occur as a consequence.

However, the discursive pattern that our results expose, as well as the stability of the rationales justifying offsetting over the past two decades, indicate that the rising hegemonies of green neoliberalism and weak ecological modernization, as well as the return of Promethean rationales, are highly likely to counter this attempt (Fig. 1, locations 17, 20 and 21). These hegemonies have imposed networks of power relationships committed to a weak sustainability framing ${ }^{18,22,28}$, limiting or undermining steering beyond the status quo (Tables 1 and 2, rows 1, 3 and 4). Without deep structural changes, NNL and offsetting are at high risk of being mobilized as 'symbolic instruments' ${ }^{45}$, discursively acting to divert attention away from more transformative action limiting and reversing the depletion of biological diversity. These issues of system inertia and incremental change found in our 
study resonate with recent environmental discourse studies devoted to climate change governance and the mobilization of carbon offsetting ${ }^{46,47}$.

\section{Reforming a radical field}

As the field of biodiversity conservation expanded and became part of transnational partnerships and regulatory state mechanisms, reformist rationales and instruments were introduced. Such moves reflect an important reconfiguration of power, with potentially major performative effects on the field itself ${ }^{14}$. This deserves further research, particularly regarding the politics of scaling, meaning the contest to define problems and their relevant temporal and spatial scales, is reconfiguring the network of power in the conservation field across continents ${ }^{14}$. It will be important to monitor the extent to which this reconfiguration is successfully transforming the field into a reformist project that produces natures compatible with development, rather than a field that advances governance systems compatible with biocultural diversity. As part of this effort, we argue that further research is needed to understand the everyday strategic practices $^{43}$ that have been deployed to give birth to the NNL agenda within conservation as well as resistance to those practices and to examine whether such practices have disseminated at subnational scales. We have demonstrated the importance of the transnational scale in these discourses, especially transnational pilot projects, voluntary guidelines, reports, academic papers and informal meetings as both key sites and outcomes of these practices.

\section{Implications for practitioners}

The post- 2020 global biodiversity framework of the $\mathrm{CBD}^{13}$ is currently being negotiated internationally as the global strategy that will replace the Aichi targets and shape the next 10 years of biodiversity conservation. A reformist project has currently been enshrined in the zero draft. This draft completes the international normalization of the NNL concept and offsetting for biodiversity and, with it, particular hegemonic understandings of human-nature relations and of biodiversity based on technical expertise. These are embedded in the proposed objective of reaching NNL for marine and terrestrial ecosystems by 2030 (Goal a), the focus on the reduction in the percentage of species threatened with extinction rather than prevention (Goal b), the absence of precise targets to address the drivers of biodiversity depletion and the mission statement stating the impossibility to completely halt biodiversity loss by $2030^{13}$.

The deep discursive pattern our analysis identifies is thus still at play. Reacting to a reformist proposition, stronger ecological modernists and some radicals are resisting and pursuing their struggles for transformative change by reframing the scope and the targets of the NNL objective. Some are attempting to refocus attention on the 'reversal of biodiversity loss', founded on the prevention of species extinction, a no-loss objective for 'key areas for biodiversity' and a net-gain objective for ecosystems ${ }^{48}$. Others more amenable to reformist commitments are embracing the NNL objective for ecosystems yet are subtly pursuing 'limits and conditions to offsetting' ${ }^{49}$.

We encourage the stakeholders involved in the negotiations for the post-2020 global biodiversity framework, as well as all actors involved in research and practice concerning offsetting, biodiversity conservation and, more generally, sustainability and its NNL policies ${ }^{2}$, to be observant of how their contributions become enrolled in the service of political projects (Tables 1 and 2). In our view, it is of utmost importance that these actors reflect on the political dimension of their work by observing the rationales invoked in policy practices, from negotiation tables to work in the field. Examining the political projects these rationales serve, the knowledges they legitimate and the ones they silence, helps clarify how they constrain policy options and shape which sustainability — weak or strong ${ }^{22}$ — can come to be. 


\section{Methods}

The research presented in this paper is grounded in a critical social sciences approach.

\section{A social constructionist approach}

A non-essentialist ontology ${ }^{50}$ and constructionist epistemology ${ }^{51}$ frame the qualitative research presented here. We assume that "human beings construct knowledge as they engage with and interpret the world" instead of unravelling an objective Truth ${ }^{52}$; and that we make sense of the world through discourses. Our research strategy thus assumes that reality cannot be directly known and, instead, is subject to competing interpretations over its meaning. It assumes that research cannot escape this constitutive effect of power. While there are different understandings of 'discourse', in this paper we adopt a Foucauldian one ${ }^{14,44}$. In attempting to understand how knowledge and power are intertwined, our approach looks at the discursive construction of social and ecological reality through texts, institutional structures, practices and events.

Following the argumentative discourse analysis literature, we define a discourse as "an ensemble of ideas, concepts and categories through which meaning is given to social and physical phenomena, and which is produced and reproduced through an identifiable set of practices"16. Thus, discourses can be said to shape who we are, what we think, what we can and will become, and what we do. Indeed, in creating meaning, a discourse and its rationales frame and produce problems, solutions, subjects, objects, places ${ }^{17}$ and human-nature relationships ${ }^{18}$. The term 'produce' is used to highlight that these entities do not exist in themselves. They are constantly created and maintained via the repetition of everyday practices. Each discourse acknowledges some forms of knowledge, shaping the assumptions on which the discourse is built, and disregards others. Through this process, some forms of knowledge are normalized and taken-for-granted truths while others are silenced. Therefore, discourses produce what truth is and who is authorized to claim specific truths. In doing so, they delimit what can be thought and done and constrain the policy options and the actors that can be empowered to solve problems; in other words, they both constrain and enable the physical realities that can come to be ${ }^{17}$.

Foucauldian scholars pay particular attention to discourses, being the location where power and knowledge meet ${ }^{44}$. Rather than seeing power as repressive forces possessed by some to dominate others, power is understood as relational, being exercised through the multiple interplays between individuals ${ }^{17,44}$. Power is defined as a "complex strategical situation in a particular society" ${ }^{44}$. It is seen as both constitutive and productive, enabling the production of specific forms of the physical reality ${ }^{17}$. Discursive practices play an important role being "both an instrument and effect of power" ${ }^{44}$. Thus, discourses articulate certain forms of truth, legitimate certain forms of knowledge and empower (and produce) specific subjects (referred to as 'actors' in this paper) at the expense of others. Discourses, the struggles between them and the knowledges they convey are thus seen as manifestations of power. It is through discursive practices that the 'power structures of society' — which form the social order-are produced and challenged ${ }^{21}$.

While actors are considered to be products of power, they are never fully determined by it. Actors and institutional structures that share the same general understanding of a given problem can form a discourse coalition ${ }^{20}$ where truth claims and specific practices obtain "meaning in a common political project" 21 . A coalition adopts and repeats specific storylines, which we refer to as 'rationales', producing and reproducing their "shared definition of reality" 21 . We consider that different discourses and their coalitions, carrying different truths, are thus constantly competing within and across societies.

Indeed, discourses and social orders are dynamic and always subject to change. "Where there is power, there is resistance" 44 : a discourse can lead to a new point of resistance within the network of power relations, triggering an opposing strategy that will challenge this discourse. Structures change when a 
new discourse becomes 'hegemonic', that is, when it has been both structured and institutionalized ${ }^{21}$. This is a dynamic and iterative process where actors incorporate and deploy concepts and rationales that are emerging as truth claims into their everyday practices in a daily political struggle to secure support for their understanding of reality ${ }^{21}$. As the discourse is being structured, actors draw on its truth claims to gain or keep their credibility ${ }^{21}$. Through this, they disseminate, translate and recontextualize these rationales and associated practices into new settings ${ }^{53}$. When rationales enter into policy texts, policy instruments and practices, the corresponding discourses become institutionalized, and more hegemonic, while other discourses and their coalitions become more marginalized. Thus, by analysing rationales present in policy-related documents and how these rationales are questioned and change through time, we can observe which discourse coalitions are successfully imposing their understanding of reality through policy texts and practices.

Discourses are always contingent and in constant flux, being challenged by other coalitions that may contest their legitimacy ${ }^{43,53}$. Observing the way discursive changes are signalled within institutional structures - such as changes in the invoked problematizations, subjects and objects in policy texts - can help identify "shifts in the relative influence of different discourses"14,51. This can signal the reconfiguration of power relations ${ }^{14}$ and the crystallization of one particular political project and truth claim at the expense of others. In other words, shifts in policy terminology, rationale or instruments are analysed as an effect of power: the result of discursive struggles among coalitions for hegemony. While some coalitions come to powerfully influence policy frames and norms, such success is temporary as other coalitions may resist through their own practices ${ }^{43}$.

In this paper, we examine this dynamic struggle and how discursive coalitions shape terminologies, rationales and policy instruments in the realm of offsetting over time and institutional scales. We conceptualize offsetting as policy instruments through which specific environmental discourses have been institutionalized across time and scales, signalling the (temporary) discursive victories of associated discourse coalitions. While rationalizing the use of offsetting, we assume that environmental discourses have also transformed its associated meanings, potentially leading to new forms of institutional arrangements.

\section{Data collection and analysis}

The data were collected and analysed using a qualitative approach. We qualitatively coded a total of 197 textual documents iteratively using NVivo 12 software $^{54}$. Texts were classified by institutional scale (Supplementary Data 1 and 2). Both descriptive and analytical codes, deriving from our conceptual framework and iteratively constructed while working with the data, were used (Supplementary Methods). The qualitative coding architecture identified changes in offsetting processes through terminology, events, actors and discursive rationales present in the texts.

Our analysis builds on previous research about the genealogy of offsetting ${ }^{8,30,55}$. We focus on five institutional scales identified in the literature and confirmed by our analysis as key in the dissemination of offsetting: the United States, Australia, Europe, international/transnational scales. The analysis started with academic and grey literature texts commonly cited in the offset literature published over the 2008-2018 period. Additional texts were then selected using snowball sampling, as each text would refer to other texts, events and actors, until saturation was reached (that is, once the relevant texts, associated events and coalitions had been identified and no new discursive dynamics were emerging to complete the narrative). This research is part of a larger research project on offsetting, for which observations and interviews were conducted in Europe and Australia. While interviews and observations were not included in the dataset for this paper, they indirectly informed our analysis regarding some key events and documents within Europe and Australia. Our dataset of texts included 
both scholarly and policy literature from 1958 to 2019, including published papers, reports, acts, presentations, commentaries and websites.

During the analysis, we differentiated between 'pivotal texts' and 'other texts'. In pivotal texts, shifts were observed regarding the terminology, rationales, actors and/or instruments at a given scale, meaning these are texts where specific understandings of offsetting were emerging or were recontextualized at a given scale. Other texts were the texts reproducing the terminology, rationales or instruments found in the pivotal texts, disseminating that understanding at a given scale. Pivotal texts entirely devoted to offsetting were read in full and coded. For other pivotal texts, we focused on reading and coding the relevant sections devoted to offsetting, authorship lists, forewords, introductions and/or acknowledgements.

For all texts, including other texts, we used a keyword search based on the offset terminology (Supplementary Methods) to locate sections devoted to offsetting, to code them when relevant and to verify the accuracy of the emerging picture in our analysis.

To associate the rationales, terminology and instruments, 'found' in the texts and coded, with their corresponding environmental discourses, we relied on existing literature on environmental governance, environmental discourses and their coalitions. This literature was read iteratively in parallel with the coding process to match discursive rationales found in the texts with their corresponding discourses. We used Dryzek's typology of nine environmental discourses ${ }^{18}$ as a general framework on how environmental discourses have emerged, disseminated and competed in environmental governance since the 1960s. Other sources from this literature ${ }^{20,22,28,46,56-63}$ were used to obtain more granular details for each discourse, including rationales, or governance changes. This scholarly literature was also used to consider potential events, actors or documents that had not previously been mentioned (to our knowledge) by the academic and grey literature on biodiversity offsetting. We rely on this literature to identify six out of the nine discourses that are most relevant for our analysis (Table 1). Our understanding of how discourses travelled across scales and time was thus iteratively constructed using both this literature and our analysis findings.

Following our conceptual framework, we interpreted textual changes in the terminology, rationales, policy instruments and actors as the signs of broader changes in the relative influence of competing environmental discourses. Shifts were interpreted as signs that specific discourse coalitions were successfully institutionalizing their discourses through these texts.

To help us keep track of our emerging interpretation despite the number of texts, time frames and institutional scales involved, we constructed a schematic figure as we were iteratively coding texts and reading the literature. The figure depicted when environmental discourses were emerging at a given scale and time, important background events and discursive conflicts, and the analysed texts (their titles, dates, institutional scale, the offset terminology and instruments they mention). The analysis of the texts allowed the corresponding discourse(s) to be identified, signalling that a particular discourse was entering or spreading in the offset realm via the named text. This enabled us to visually represent how the discourses, their offset rationales and terminologies travelled through texts from one scale to another across time. Figure 1 and Box 1 are the simplified outcome of this interpretative work, showing the schematic representation of the emergence, dissemination and recontextualization of environmental discourses, key moments of discursive tensions and associated changes in offsetting terminology and instruments across institutional scales and time.

\section{Limitations of the research strategy}

Our research strategy relies on Dryzek's typology and other scholarly literature on environmental discourses. This enabled us to produce a qualitative meta-study across various scales (a rare enterprise 
in the discourse literature, often focused on single-case studies ${ }^{15}$ ) and to focus on the effects of discourses on a policy instrument and actors across time and various policy arenas, rather than on the discourses themselves. Yet as highlighted in the discourse literature ${ }^{15}$, the use of existing knowledge on environmental discourses has limited our engagement with the discursive nuances across texts and our capacity to capture potentially novel discursive rationales, particularly in the most recent texts. In particular, the diversity of rationales invoked among radical coalitions, notably as they more recently reacted to and interacted with the rise of a strong ecological modernist coalition, could not be investigated. Moreover, as the analysis focused on English texts, yet studied a policy instrument deployed in non-English-speaking contexts, we could not investigate the nuances brought as rationales were harnessed, translated and adapted in non-English texts. Despite this, a surprising finding of the research was the stability of the rationales justifying offsetting through time and the clear shifts in terminologies as new discourse coalitions, relying on the key rationales well established in the literature, were emerging and becoming hegemonic in policy documents. As a consequence, if we may have missed some discursive innovations, our analysis suggests they would have limited ability to influence the meanings of offsetting found in international and transnational policy texts. 


\section{References}

1. Bull, J. W., Gordon, A., Watson, J. E. M. \& Maron, M. Seeking convergence on the key concepts in 'no net loss' policy. J. Appl. Ecol. 53, 1686-1693 (2016).

2. Maron, M. et al. The many meanings of no net loss in environmental policy. Nat. Sustain 1, 19-27 (2018).

3. Bull, J. W. \& Strange, N. The global extent of biodiversity offset implementation under no net loss policies. Nat. Sustain 1, 790-798 (2018).

4. von Hase, A. \& ten Kate, K. Correct framing of biodiversity offsets and conservation: a response to Apostolopoulou \& Adams. Oryx 51, 32-34 (2017).

5. Standard on Biodiversity Offsets (BBOP, Forest Trends, 2012).

6. Zu Ermgassen, S. O. S. E. et al. The ecological outcomes of biodiversity offsets

under "no net loss" policies: a global review. Conserv. Lett. https://doi.org/10.1111/conl.12664 (2019).

7. Moreno-Mateos, D., Maris, V., Béchet, A. \& Curran, M. The true loss caused by biodiversity offsets. Biol. Conserv. 192, 552-559 (2015).

8. Bonneuil, C. Tell me where you come from, I will tell you who you are: a genealogy of biodiversity offsetting mechanisms in historical context. Biol. Conserv. 192, 485-491 (2015).

9. Boon, P. I. \& Prahalad, V. Ecologists, economics and politics: problems and contradictions in applying neoliberal ideology to nature conservation in Australia. Pac. Conserv. Biol. 23, 115-132 (2017).

10. Penca, J. Marketing the market: the ideology of market mechanisms for biodiversity conservation. Transnatl Environ. Law 2, 235-257 (2013).

11. Lapeyre, R., Froger, G. \& Hrabanski, M. Biodiversity offsets as market-based instruments for ecosystem services? From discourses to practices. Ecosyst. Serv. 15, 125-133 (2015).

12. Hackett, R. Market-based environmental governance and public resources in Alberta, Canada. Ecosyst. Serv. 15, 174-180 (2015).

13. Zero Draft of the Post-2020 Global Biodiversity Framework (CBD, 2020). 14. Feindt, P. H. \& Oels, A. Does discourse matter? Discourse analysis in environmental policy making. J. Environ. Policy Plan. 7, 161-173 (2005).

15. Leipold, S., Feindt, P. H., Winkel, G. \& Keller, R. Discourse analysis of environmental policy revisited: traditions, trends, perspectives. J. Environ. Policy Plan. 21, 445-463 (2019).

16. Hajer, M. \& Versteeg, W. A decade of discourse analysis of environmental politics: achievements, challenges, perspectives. J. Environ. Policy Plan. 7, 175-184 (2005).

17. Bacchi, C. \& Goodwin, S. Poststructural Policy Analysis: A Guide to Practice (Springer, 2016).

18. Dryzek, J. S. The Politics of the Earth: Environmental Discourses (Oxford Univ. Press, 2013).

19. Foucault, M. The History of Sexuality: An Introduction Vol. 1(Penguin Group, 2008).

20. Hajer, M. A. in Words Matter in Policy and Planning: Discource Theory and Method in the Social Sciences (eds Van den Brink, M. \& Metze, T.) 65-76 (Netherlands Graduate School of Urban and Regional Research, 2006).

21. Hajer, M. A. The Politics of Environmental Discourse: Ecological Modernization and the Policy Process (Clarendon Press, 1995).

22. Hopwood, B., Mellor, M. \& O’Brien, G. Sustainable development: mapping different approaches. Sustain. Dev. 13, 38-52 (2005).

23. Carson, R. Silent Spring (Houghton Mifflin, 1962).

24. Our Common Future (United Nations World Commission on Environment and Development, Oxford Univ. Press, 1987).

25. Robertson, M. M. The neoliberalization of ecosystem services: wetland mitigation banking and problems in environmental governance. Geoforum 35, 361-373 (2004).

26. Clapp, J. \& Dauvergne, P. in Paths to a Green World: The Political Economy of the Global Environment (eds Clapp, J. \& Dauvergne, P.) 161-191 (MIT Press, 2011).

27. Werksman, J. The clean development mechanism: unwrapping the Kyoto surprise. Rev. Eur. Comp. Int. Environ. Law 7, 147-158 (1998).

28. Christoff, P. Ecological modernisation, ecological modernities. Environ. Polit. 5, 476-500 (1996).

29. Breaking New Ground: The Report of the Mining, Minerals and Sustainable Development Project (International Institute for Environment and Development, World Business Council for Sustainable Development,

Earthscan Publications, 2002). 
30. Hrabanski, M. The biodiversity offsets as market-based instruments in global governance: origins, success and controversies. Ecosyst. Serv. 15, 143-151 (2015).

31. Ecosystems and Human Well-Being: Our Human Planet: Summary for Decision Makers (Millennium Ecosystem Assessment, 2005); http://millenniumassessment.org/en/Global.html

32. The Economics of Ecosystems and Biodiversity: Mainstreaming the Economics of Nature: A Synthesis of the Approach, Conclusions and Recommendations of TEEB (TEEB, 2010); http://teebweb.org/publications/teebfor/synthesis/

33. Bassey, N. et al. IUCN Withdrawal (Friends of the Earth International, 2009).

34. WWC 10 Final Resolution 12: Building a Global Alliance to Assert 'No-Go Areas'for Mining and Other Extractive Industries and Destructive Activities Threatening World Heritage Sites, and Protected Areas, including Indigenous Peoples' and Local Communities Conserved Areas and Territories (ICCAs) and Sacred Natural Sites and Territories (WWC, 2013).

35. WCC-2012-Res-110-EN: Biodiversity Offsets and Related Compensatory Approaches (WCC, 2012).

36. IUCN Resolutions, Recommendations and Other Decisions (IUCN, 2016).

37. Permitted Clearing of Native Vegetation: Biodiversity Assessment Guidelines (The Victorian Government, Department of Environment and Primary Industries, 2013).

38. NSW Biodiversity Offsets Policy for Major Projects (State of NSW, Office of Environment and Heritage, 2014).

39. Our Evolving Approach to Biodiversity: The Next Chapter in Biodiversity Management (Rio Tinto, 2017); http://www.riotinto.com/ourcommitment/spotlight-18130_21621.aspx

40. Konisky, D. M. \& Woods, N. D. Environmental federalism and the Trump presidency: a preliminary assessment. Publius 48, 345-371 (2018).

41. Working for Biodiversity Net Gain: An Overview of the Business and Biodiversity Offsets Programme (BBOP) 2004-2018 (BBOP, Forest Trends, 2018).

42. Summary for Policymakers of the Global Assessment Report on Biodiversity and Ecosystem Services of the Intergovernmental Science-Policy Platform on Biodiversity and Ecosystem Services (IPBES Secretariat, 2019).

43. Leipold, S. \& Winkel, G. Discursive agency: (re-)conceptualizing actors and practices in the analysis of discursive policymaking. Policy Stud. J. 45, 510-534 (2017).

44. Foucault, M. The History of Sexuality: The Will to Knowledge Vol. I (Penguin Group, 2008).

45. Walker, S., Brower, A. L., Stephens, R. T. T. \& Lee, W. G. Why bartering biodiversity fails. Conserv. Lett. 2 , 149-157 (2009).

46. Bäckstrand, K. \& Lövbrand, E. The road to Paris: contending climate governance discourses in the postCopenhagen era. J. Environ. Policy Plan. 21, 519-532 (2016).

47. Griggs, S. \& Howarth, D. Discourse, policy and the environment: hegemony, statements and the analysis of UK airport expansion. J. Environ. Policy Plan. 21, 464-478 (2019).

48. Reflections on the Zero Draft Post-2020 Global Biodiversity Framework (BirdLife International, 2020).

49. IUCN Position: Zero Draft of the Post-2020 Global Biodiversity Framework (IUCN, 2020); https://go.nature.com/3kEA4rP

50. Dingler, J. The discursive nature of nature: towards a post-modern concept of nature. J. Environ. Policy Plan. 7, 209-225 (2005).

51. Sharp, L. \& Richardson, T. Reflections on Foucauldian discourse analysis in planning and environmental policy research. J. Environ. Policy Plan. 3, 193-209 (2001).

52. Moon, K. \& Blackman, D. A guide to understanding social science research for natural scientists. Conserv. Biol. 28, 1167-1177 (2014).

53. Fairclough, N. Critical discourse analysis. Marges Linguist. 9, 76-94 (2005).

54. NVivo qualitative data analysis software (QSR International, 2019); https://www.qsrinternational.com/nvivo/home

55. Calvet, C., Ollivier, G. \& Napoleone, C. Tracking the origins and development of biodiversity offsetting in academic research and its implications for conservation: a review. Biol. Conserv. 192, 492-503 (2015).

56. Darier, É. (ed.) Discourses of the Environment (Blackwell, 1999).

57. Bäckstrand, K. \& Lövbrand, E. in The Social Construction of Climate Change: Power, Knowledge, Norms, Discourses (ed. Pettenger, M. E.) 123-147 (Taylor \& Francis Group, 2007). 
58. Mol, A. P. J., Spaargaren, G. \& Sonnenfeld, D. A. in The Ecological Modernisation Reader. Environmental Reform in Theory and Practice (eds Mol, A. P. J. et al.) 3-14 (Routledge, 2009).

59. Nilsen, H. R. The joint discourse 'reflexive sustainable development'-from weak towards strong sustainable development. Ecol. Econ. 69, 495-501 (2010).

60. Jacobs, M. in The Handbook of Global Climate and Environment Policy (ed. Falkner, R.) 197-214 (John Wiley \& Sons, 2013); https://doi.org/10.1002/9781118326213.ch12

61. Ferguson, P. The green economy agenda: business as usual or transformational discourse? Environ. Polit. 24, 17-37 (2015).

62. Coffey, B. Unpacking the politics of natural capital and economic metaphors in environmental policy discourse. Environ. Polit. 25, 203-222 (2016).

63. Bakker, K. The limits of 'neoliberal natures': debating green neoliberalism. Prog. Hum. Geogr. 34, 715-735 (2010). 


\section{Acknowledgements}

We acknowledge the people of the Woi wurrung and Boon wurrung language groups of the eastern Kulin Nations on whose unceded lands this research was undertaken. We respectfully acknowledge their Elders, past, present and emerging.

This research was conducted with support from the Australian Research Council (ARC) through Discovery Project DP150103122 and from the European Union and RMIT University through a cofunded EU Centre HDR Travel Grant. We thank C. Koeleman for her expertise support in the design of Fig. 1 and B. Coffey for informal discussions on discourses in Australia and for providing us with relevant references on environmental discourses.

\section{Author contributions}

F.L.P.D. and A.G. developed the initial idea. F.L.P.D. developed the research approach, collected the data, conducted the analysis and wrote the manuscript. A.G. and L.P. contributed ideas to the study design and edited the manuscript. A.G. contributed experience and perspective on the evolution of offset policies, and L.P. contributed experience and knowledge regarding the conceptual framework, qualitative analysis methods and sustainability governance.

\section{Competing interests}

The authors declare no competing interests. 